Jurnal Ekonomi dan Industri

e-ISSN: $2656-3169$

Volume 22, No.2, Mei-Agustus 2021

p- ISSN: 0853-5248

\title{
ANALISIS KEBANGKRUTAN PERUSAHAAN SUB SEKTOR COAL MINING DI BURSA EFEK INDONESIA
}

\author{
Ayu Puspitaningtyas 1) \\ Dhistianti Mei Rahmawan Tari ${ }^{2)}$ \\ 1) dan, 2) Dosen Program Studi Manajemen FE UNKRIS \\ Alamat: Kampus UNKRIS, Jatiwaringin Jakarta Timur \\ Email : ayundyla@gmail.com, dhistianti@unkris.ac.id
}

\begin{abstract}
This study aims to determine the level of potential bankruptcy of a company. In this study, the company under study is coal mining sector listed on the IDX SMC Liquid. The companies include PT Adaro Energy Tbk (ADRO), PT Indika Energy Tbk(INDY), PT Indo Tambangraya Megah Tbk (ITMG) and PT Bukti Asam Tbk (PTBA). To research the company, researchers use 2 methods, namely the method of Altman and Grover and as a first step in knowing the bankruptcy signal of the company early. This type of research is descriptive quantitative. The data source used is secondary data. Population in this research is coal mining on IDX SMC Liquid issuer amounting to 4 coal mining company in period 2017-2020. The sample of research is using probability sampling method. The results of this study indicate that there are 2 methods used and generally have differences in the results of calculations, as well as publicly listed coal mining companies doesn't have the potential to experience bankruptcy. Of the 2 methods used that are most accurate in determining the prediction of freedom is the Grover method.
\end{abstract}

Keywords: Bankruptcy, Altman Z-score, Grover, Coal Mining Company

\section{PENDAHULUAN}

Negara-negara penghasil batu bara terbesar di dunia telah berperan banyak dalam memberikan sumber daya guna indutrialisasi di pasar global. Di antaranya melalui pembangkit listrik termal dan sebagai bahan untuk proses manufaktur seperti pembuatan baja.

Batu bara tetap menjadi sumber pembangkit listrik terbesar di dunia di tengah upaya global dalam mengurangi penggunaan batu bara. Badan Energi International atau IEA pada 2019 menyatakan bahwa batu bara memegang 38 persen dari keseluruhan pangsa sumber pembangkit listrik global.

Produksi batu bara dunia pun meningkat dari tahun ke tahun, terhitung sejak 2016 silam. Sementara, cadangan batu bara global tercatat ada lebih dari satu triliun ton. Data IEA menunjukkan bahwa total produksi batu bara dunia berhasil mencapai 7,9 miliar ton pada 2019, yang merupakan tertinggi sejak 2014. Batu bara termal dan lignit menghasilkan sekitar 86 persen dari produksi tersebut dan sisanya adalah batu bara metalurgi.

Pandemik COVID-19 pada awal tahun 2020 kemudian menunjukkan penurunan produksi global sebesar 6,5 persen lantaran minimnya permintaan selama periode tersebut. Namun, tahun 2021 diprediksi akan meningkat menjadi 7,6 juta ton.

Indonesia merupakan salah satu penghasil batu bara terbesar di dunia dengan menduduki peringkat keempat menurut NS Energy Profile setelah Amerika, India dan Tiongkok. Merujuk informasi dari Minerba One Data (MODI) Ditjen Minerba Kementerian ESDM, realisasi produksi batubara tahun 2020 mencapai 557,54 juta ton. Angka itu tipis di atas rencana produksi nasional tahun 2020 yang ditetapkan sebanyak 550 juta ton. Artinya, realisasi produksi tahun 2020 101,37\% dari target. Dari sisi penjualan, realisasi ekspor yang 
tercatat di MODI sebanyak 305,77 juta ton atau 77,41\% dari rencana ekspor yag berada di angka 395 juta ton. Sedangkan untuk Domestic Market Obligation (DMO), realisasi yang tercatat di MODI sebesar 108,45 juta ton atau 69,97\% dari rencana yang ditetapkan 155 juta ton.

Komoditas batubara pada tahun 2020 memang dibayangi dengan tekanan pasar dan harga sebagai imbas dari pandemi covid-19. Namun, kondisi pasar dan harga batubara mulai membaik pada tiga bulan terakhir 2020, dan berlanjut di awal 2021. Kondisi itu tercermin dari Harga Batubara Acuan (HBA) yang terus menunjukkan tren yang menanjak. HBA 2021 dibuka dengan US\$75,84 per ton. HBA bulan Januari 2021 itu naik US\$16,19 per ton atau 27,14\% dibandingkan bulan Desember tahun 2020, yaitu US\$ 59,65 per ton.

Mewaspadai tentang kondisi pasar dan harga yang belum tentu stabil dalam waktu panjang, maka hal yang harus diperhatikan yaitu pada kinerja keuangan untuk mengantisipasi terjadinya kebangkrutan pada perusahaan. Dimana laporan keuangan merupakan media 3 informasi yang merangkum semua aktivitas suatu perusahaan. Dengan persaingan yang semakin kuat ini menuntut perusahaan untuk memperkuat fundamental agar perusahaan dapat bersaing dengan perusahaan yang sejenis. Apabila perusahaan tidak mampu mempertahankan perusahaan maka akan mengakibatkan penurunan kinerja keuangan perusahaan, sehingga mengakibatkan perusahaan bangkrut. Laporan keuangan dapat memberikan informasi lengkap tentang status perusahaan dan informasi lainnya, seperti informasi tentang industri dan kondisi ekonomi, sehingga dapat memberikan gambaran mengenai prospek dan resiko perusahaan. (Harahap, 2004).

Selain itu perusahaan juga harus mampu memenuhi tuntutan permintaan pasar yang semakin intens akan kebutuhannya. Terlebih dalam hal kondisi perekonomian Indonesia yang terus mengalami kritis sehingga memaksa perusahaan untuk beradaptasi dengan kondisi tersebut, yaitu dengan meningkatkan nilai tambah perusahaan. Potensi kebangkrutan tentunya akan memberikan kekhawatiran suatu perusahaan dan berbagai pihak baik sektor internal maupun pihak eksternal, serta pihak investor yang telah menanamkan modal atau dana diperusahaan tersebut. Darsono dan Ashari (2005) menjelaskan bahwa kebangkrutan merupakan kondisi kesulitan keuangan yang dapat diartikan ketidakmampuan perusahaan dalam membayar seluruh kewajiban keuangannya pada saat jatuh tempo.

Dalam hal analisis kebangkrutan adapun beberapa metode yang digunakan yaitu formula metode altman z-score, metode springate, metode grover dan metode zmijewski. Analisis kebangkrutan selain menggunakan metode yang sederhana dan rumus yang telah ditentukan untuk menentukan prediksi kebangkrutan dengan hasil yang akurat. Analisis kebangkrutan tersebut dilakukan untuk memprediksi suatu perusahaan sebagai penilai dan bahan pertimbangan kinerja perusahaan. (Peter dan Yoseph, 2011)

Untuk menilai kinerja suatu perusahaan dapat dilakukan analisis terhadap laporan keuangan perusahaan. Analisis terhadap laporan keuangan dilakukan dengan menggunakan rasio-rasio keuangan, seperti rasio likuiditas, leverage, aktivitas, profitabilitas dan rasio pasar.

\section{LANDASAN TEORI}

\section{Indeks Saham}

Indeks saham adalah ukuran statistik yang mencerminkan keseluruhan pergerakan harga atas sekumpulan saham yang dipilih berdasarkan kriteria dan metodologi tertentu serta dievaluasi secara berkala.

Tujuan/manfaat dari indeks saham antara lain: 1). Mengukur sentimen pasar, Dijadikan produk investasi pasif seperti Reksa Dana Indeks dan ETF Indeks serta produk 
turunan, 3). Benchmark bagi portofolio aktif, 4). Proksi dalam mengukur dan membuat model pengembalian investasi (return), risiko sistematis, dan kinerja yang disesuaikan dengan risiko, serta 5). Proksi untuk kelas aset pada alokasi aset.

Jenis-jenis indeks saham di Indonesia antara lain: 1). Indeks Harga Saham Gabungan (IHSG); Indeks yang mengukur pergerakan semua saham yang tercatat di Bursa Efek Indonesia. 2). Indeks LQ45; Indeks yang mengukur performa harga dari 45 saham-saham yang memiliki likuiditas tinggi dan kapitalisasi pasar besar serta didukung oleh fundamental perusahaan yang baik. 3). Indeks IDX30; Indeks yang mengukur performa harga dari 30 saham-saham yang memiliki likuiditas tinggi dan kapitalisasi pasar besar serta didukung oleh fundamental perusahaan yang baik. 4). Indeks IDX80; Indeks yang mengukur performa harga dari 80 saham-saham yang memiliki likuiditas tinggi dan kapitalisasi pasar besar serta didukung oleh fundamental perusahaan yang baik. 5). Indeks KOMPAS100; Indeks yang mengukur performa harga dari 100 saham-saham yang memiliki likuiditas yang baik dan kapitalisasi pasar yang besar. Indeks KOMPAS100 diluncurkan berkerja sama dengan perusahaan media KOMPAS GRAMEDIA. 6). Indeks IDX SMC Composite / IDX Small-Mid Cap Composite Index; Indeks yang mengukur performa harga dari saham-saham yang memiliki kapitalisasi pasar kecil dan menengah. 7). Indeks IDX SMC Liquid / IDX Small-Mid Cap Liquid Index; Indeks yang mengukur performa harga dari saham-saham dengan likuiditas tinggi yang memiliki kapitalisasi pasar kecil dan menengah. Konstituen Indeks IDX SMC Liquid diambil dari konstituen Indeks IDX SMC Composite. 8). Indeks IDX High Dividend 20/ IDX High Dividend 20 Index; Indeks harga atas 20 saham yang membagikan dividen tunai selama 3 tahun terakhir dan memiliki dividend yield yang tinggi. 9). Indeks IDX BUMN20/ IDX BUMN20 Index; Indeks yang mengukur performa harga harga atas 20 saham perusahaan tercatat yang merupakan Badan Usaha Milik Negara (BUMN), Badan Usaha Milik Daerah (BUMD), dan afiliasinya. 10). Indeks Saham Syariah Indonesia/ Indonesia Sharia Stock Index (ISSI); Indeks yang mengukur performa harga seluruh saham yang dinyatakan sebagai saham syariah sesuai dengan Daftar Efek Syariah (DES) yang ditetapkan oleh Otoritas Jasa Keungan (OJK). 11). Jakarta Islamic Index (JII); Indeks yang mengukur performa harga dari 30 saham-saham syariah yang memiliki kinerja keuangan yang baik dan likuiditas transaksi yang tinggi. 12). Jakarta Islamic Index 70 (JII70); Indeks yang mengukur performa harga dari 70 saham-saham syariah yang memiliki kinerja keuangan yang baik dan likuiditas transaksi yang tinggi. 13). Indeks Sektoral; Indeks yang mengukur performa harga seluruh saham dari masing-masing sektor industri yang terdapat pada klasifikasi Jakarta Stock Industrial Classification (JASICA). Indeks ini terdiri dari: a). Indeks Pertanian; b). Indeks Pertambangan; c). Indeks Industri Dasar dan Kimia; d). Indeks Aneka Industri; e). Indeks Industri Barang Konsumsi; f). Indeks Properti, Real Estat, dan Konstruksi Bangunan; g). Indeks Infrastruktur, Utilitas, dan Transportasi; h). Indeks Keuangan; i). Indeks Perdagangan, Jasa, dan Investasi; j). Indeks Manufaktur. 14). Indeks Papan Pencatatan (Board Index); Indeks yang mengukur performa harga seluruh saham tercatat sesuai dengan papan pencatatannya yaitu Utama dan Pengembangan. Suatu saham masuk pada papan pencatatan Utama atau Pengembangan sesuai dengan ketentuan pencatatan saham di BEI. Indeks ini terdiri dari: a). Indeks Papan Utama (Main Board Index); b). Indeks Papan Pengembangan (Development Board Index). 15). Indeks BISNIS-27; Indeks yang mengukur performa harga dari 27 saham-saham yang dipilih oleh Komite Indeks Bisnis Indonesia. Indeks BISNIS-27 diluncurkan berkerja sama dengan perusahaan media PT Jurnalindo Aksara Grafika (penerbit surat kabar harian Bisnis Indonesia). 16). Indeks PEFINDO25; Indeks yang mengukur performa harga saham dari 25 emiten kecil dan menengah yang memiliki kinerja keuangan yang baik dan likuiditas transaksi yang tinggi. Indeks PEFINDO25 diluncurkan dan dikelola berkerja sama dengan 
perusahaan pemeringkat PT Pemeringkat Efek Indonesia (PEFINDO). 17). Indeks SRIKEHATI; Indeks yang mengukur performa harga saham dari 25 emiten yang memiliki kinerja yang baik dalam mendorong usaha-usaha berkelanjutan, serta memiliki kesadaran terhadap lingkungan hidup, sosial, dan tata kelola perusahaan yang baik atau disebut Sustainable and Responsible Investment (SRI). Indeks SRI-KEHATI diluncurkan dan dikelola berkerja sama dengan Yayasan Keanekaragaman Hayati Indonesia (Yayasan KEHATI). 18). Indeks infobank15; Indeks infobank15 adalah indeks yang terdiri dari 15 saham perbankan yang memiliki faktor fundamental yang baik dan likuiditas perdagangan yang tinggi. Indeks infobank15 diluncurkan dan dikelola berkerja sama dengan perusahaan media PT Info Artha Pratama (penerbit Majalah Infobank). 19). Indeks SMinfra18; Indeks SMinfra18 adalah indeks yang terdiri dari 18 saham yang konstituennya dipilih dari sektorsektor infrastruktur, penunjang infrastruktur, dan pembiayaan infrastruktur (dari sektor perbankan) yang dipilih berdasarkan kriteria tertentu. Indeks SMinfra18 diluncurkan dan dikelola berkerja sama dengan PT Sarana Multi Infrastruktur (Persero) (SMI). 20). Indeks MNC36; Indeks yang terdiri dari 36 saham yang memiliki kinerja positif yang dipilih berdasarkan kapitalisasi pasar, likuiditas transaksi, dan fundametal serta rasio keuangan. Indeks MNC36 diluncurkan dan dikelola berkerja sama dengan perusahaan media Media Nusantara Citra (MNC) Group. 21). Indeks Investor33; Indeks yang mengukur performa harga 33 saham yang dipilih dari 100 (seratus) Perusahaan Tercatat terbaik versi Majalah Investor yang dipilih berdasarkan kapitalisasi pasar, likuiditas transaksi dan fundamental serta rasio keuangan. Indeks Investor33 diluncurkan dan dikelola berkerja sama dengan perusahaan media PT Media Investor Indonesia (penerbit Majalah Investor). 22). Indeks PEFINDO i-Grade / PEFINDO Investment Grade Index; Indeks yang mengukur performa harga dari 30 saham emiten-emiten yang memiliki peringkat investment grade dari PEFINDO (idAAA hingga idBBB-) yang berkapitalisasi pasar paling besar. Indeks PEFINDO i-Grade diluncurkan dan dikelola berkerja sama dengan perusahaan pemeringkat PT Pemeringkat Efek Indonesia (PEFINDO).

\section{Indeks SMC Liquid}

Bursa Efek Indonesia memiliki indeks IDX Small-Mid Cap (SMC) Liquid yang diluncurkan sejak 21 Desember 2017 dengan base date 30 Januari 2009. Indeks SMC Liquid adalah indeks yang mengukur kinerja harga saham yang memiliki kapitalisasi pasar menengah dan kecil serta dipilih berdasarkan kriteria tertentu seperti likuiditas dan kinerja fundamental. Ada 54 saham yang menjadi anggota (konstituen) indeks ini. Saham yang masuk ini diseleksi secara umum dari indeks IDX SMC Composite (indeks lain di BEI) dan sudah menjadi perusahaan terbuka setidaknya 6 bulan. Secara khusus, indeks ini dipilih berdasarkan nilai transaksi di pasar reguler, kapitalisasi pasar, harga saham serta kinerja keuangan, keberlanjutan bisnis serta pembahasan oleh analis. Indeks ini ditinjau secara berkala setiap enam bulan sekali pada Januari dan Juli. Artinya, ada saham yang bertahan dalam indeks ini dan ada pula yang dikeluarkan.

\section{Financial Distress}

Menurut Brahmana (2007) mengatakan bahwa jika laba perusahaan, laba bersih dan nilai buku ekuitas menunjukkan angka negatif maka akan dapat dikatakan perusahaan tersebut sedang menghadapi kesulitan keuangan. Studi lain yang diterbitkan pada tahun 2013 yang dipimpin oleh Hanifah juga menjelaskan bahwa fenomena financial distress lainnya adalah perusahaan sering mengalami kesulitan likuiditas yang ditunjukkan dengan kemampuan perusahaan dalam memenuhi kewajibannya kepada kreditur yang akan menurun seiring berjalannya waktu. 
Financial distress juga sering terjadi pada perusahaan yang tidak mampu lagi atau tidak lagi memenuhi kewajibannya yang disebabkan oleh ketidakcukupan atau kekurangan dana untuk melanjutkan operasional usahanya.

Adapun pendapat menurut Fahmi (2011) membagi beberapa kondisi financial distress menjadi empat kategori, yaitu: 1). Financial Distress Kategori A; Kategori ini akan menyebabkan perusahaan dapat dikatakan bangkrut. Dalam kategori ini, perusahaan dapat melaporkan kepada beberapa pihak terkait seperti perusahaan yang dinyatakan pailit dan semua urusannya ditangani oleh pihak di luar perusahaan. 2). Financial Distress Kategori B; Dalam kategori ini, perusahaan harus mempertimbangkan solusi yang tepat untuk menyelamatkan berbagai aset perusahaa, seperti aset yang akan dijual dan diplihara, termasuk pertimbangan segala dampak yang akan terjadi jika kebijakan merger dan akuisisi perusahaan terpengaruh. Salah satu dampak nyata yang dapat dilihat dari situasi ini adalah perusahaan akan mulai menerapkan kebijkan PHK dan pensiun dini bagi karyawan tertentu yang dianggap tidak layak untuk retensi. 3). Financial Distress Kategori C; Dalam hal ini, perusahaan harus melakukan berbagai perusahan terhadap beberapa kebijakan dan konsep manajemen yang telah diterapkan, bahkan perusahaan juga dapat merekrut tenaga ahli baru yang memiliki kemampuan lebih tinggi untuk menduduki berbagai posisi strategis, yang bertanggung jawab untuk menjaga dan mengendalikan perusahaan. Termasuk tujuan perusahaan untuk meningkatkan laba. 4). Financial Distress Kategori D; Dalam kategori yang keempat ini, perusahaan dianggap hanya mengalami fluktuasi keuangan sementara yang disebabkan oleh berbagai kondisi internal dan eksternal (termasuk karena keputusan yang tidak tepat). Kesulitan keuangan perusahaan ditampilkan sebagai proses tiga dimensi, termasuk kerangka waktu, kesulitan keuangan dan tahapan proses. Siklus kesulitan keuangan perusahaan mencakup seluruh periode ketika kinerja awalnya turun ke titik terendah. Hingga perusahaan dapat memperbaikin kinerjanya kembali. Disaat perusahaan mengalami kesulitan keuangan, maka persahaan tersebut dikatakan tidak dalam kondisi keuangan yan baik dan harus melakukan evaluasi ke tahap yang baru. Jika performanya dinilai makin memburuk, maka perusahaan tersebut dinyatakan mengalami kebangkrutan dan sebaliknya jika perfomanya membaik maka perusahaan tersebut mendapatkan kesempatan untuk mengatasi kesulitan keuangan.

Empat variabel yang menunjukkan perbedaan antara perusahaan yang bangkrut dengan yang tidak bangkrut adalah: 1). Tingkat return (rate of return), perusahaan yang bangkrut mempunyai tingkat return yang lebih rendah. 2). Penggunaan hutang, perusahaan yang bangkrut menggunakan hutang yang lebih tinggi. 3). Perlindungan terhadap biaya tetap (Fixed payment coverage), perusahaan yang bangkrut mempunyai perlindungan terhadap biaya tetap yang lebih kecil. 4). Fluktuasi return saham, perusahaan yang bangkrut mempunyai rata-rata return yang lebih rendah dan mempunyai fluktuasi return saham yang lebih tinggi.

Menurut Pustylnick (2012), terdapat dua solusi apabila perusahaan mempunyai arus kas yang negatif, yaitu: 1). Restrukturiasi hutang; Manajemen dapat melakukan restrukturisasi hutang dengan meminta perpanjangan waktu dari kreditur untuk melunasi kewajibannya, sehingga perusahaan mempunyai kas yang cukup untuk memenuhi kewajiban tersebut. 2). Perubahan dalam manajemen; Apabila diperlukan, perusahaan dapat mengambil langkah penggantian jajaran manajemen perusahaan dengan orang yang lebih kompeten. Dengan bergitu kepercayaan dari stakeholder mungkin saja dapat dikembalikan. Hal ini dilakukan untuk menghindari larinya investor potensial perusahaan dikarenakan potensi kebangkrutan yang membayangi perusahaan.

\section{Analisis Prediksi Kebangkrutan}


Analisis prediksi kebangkrutan merupakan analisis yang dapat membantu perusahaan untuk mengantisipasi kemungkinan perusahaan akan mengalami kebangkrutan yang disebabkan oleh masalah-masalah keuangan.

\section{Metode Altman Z-Score}

Z-Score merupakan skor yang telah ditentukan dari hitungan standar yang akan menunjukkan tingkat kemungkinan kebangkrutan perusahaan. Formula Z-Score untuk memprediksi kebangkrutan dari Altman merupakan sebuah multivariate formula yang digunakan untuk mengukur kesehatan finansial dari sebuah perusahaan. (Altman, 2005).

Penggunaan model Altman adalah sebagai salah satu pengukuran kinerja kebangkrutan tidak bersifat tetap melainkan berkembang dari waktu ke waktu, dimana pengujian dan penemuan model terus di evaluasi dan diperluas oleh Altman hingga penerapannya tidak hanya pada perusahaan manufaktur publik saja tapi sudah mencakup perusahaan manufaktur non publik dan perusahaan obligasi.

Berikut adalah perkembangan model Altman antara lain (Effendi, 2018): 1). Metode Altman Original (1968); Metode prediksi kebangkrutan ini dipelopori oleh Beaver pada tahun (1966) dalam penelitiannya Beaver mengidentifikasikan 30 rasio yang dianggap mewakili berbagai aspek yang relevan. Dan dikembangkan oleh Altman (1968) berdasarkan model yang telah dikembangkan tersebut, Teknik analisis yang dihasilkan adalah berbagai jenis perusahaan manufaktur di Amerika Serikat yang menjual sahamnya di bursa efek. Altman menggunakan sample riset sebanyak 66 perusahaan, dimana perusahaan tersebut terdiri dari 33 perusahaan yang bangkrut pada rentang waktu 20 tahun kebelakang, serta 33 perusahaan yang diambil secara random yang mana perusahaan-perusahaan tersebut tidak mengalami kebangkrutan. Karena rumus ini lebih cocok digunakan untuk keberlangsungan suatu perusahaan manufaktur yang Go Public.

Setelah melakukan penelitian terhadap variabel dan sampel yang dipilih, Altman menghasilkan model kebangkrutan yang pertama. Persamaan tersebut ditunjukkan untuk memprediksi sebuah perusahaan publik manufaktur. Persamaan yang dihasilkan dari model altman pertama, yaitu:

$$
\mathrm{Z}=1,2 \mathrm{X} 1+1,4 \mathrm{X} 2+3,3 \mathrm{X} 3+0,6 \mathrm{X} 4+0,999 \mathrm{X} 5
$$

Keterangan:

$$
\begin{aligned}
& \mathrm{Z}=\text { Bankcrupty Index } \\
& \mathrm{X}_{1}=\text { Working Capital } / \text { Total Assets } \\
& \mathrm{X}_{2}=\text { Retained Earnings /Total Assets } \\
& \mathrm{X}_{3}=\text { Earning Before Interest And Taxes/Total Assets } \\
& \mathrm{X}_{4}=\text { Book Value Of Equity / Book Value Of Total Liabilities } \\
& \mathrm{X}_{5}=\text { Sales /Total Assets }
\end{aligned}
$$

Nilai Z-Score adalah indeks kumulatif dari fungsi multiple discriminant analysis yang memperhitungkan keseluruhan yang menjadi indikator terjadinya distress pada perusahaan. Terdapat angka cut off dari Z-Score yang menjadi penentu akhir apakah perusahaan tersebut berada dalam kondisi sehat, grey area atau mengalami kebangkrutan.

Pengklasifikasikan tingkat kesehatan perusahaan menjadi tiga kategori, yaitu: a). Jika nilai $Z<1,8$ artinya perusahaan yang bersangkutan mengalami distress atau kesulitan dalam keuangan dan potensial bangkrut. b). Jika nilai yang diperoleh $1,8<\mathrm{Z}<2,99$ artinya perusahaan termasuk kedalam kategori grey area, dimana pada kondisi ini tidak dapat ditentukan apakah perusahaan tersebut dalam keadaan sehat atau mengalami distress. c). Dan jika diperoleh nilai $Z>2,99$ artinya perusahaan tergolong sehat dan tidak bangkrut. 
2). Metode Altman Revisi (1983); Pada metode revisi ini dikembangkan kembali oleh Altman yang merupakan penyesuaian, agar model prediksi kebangkrutan ini tidak hanya untuk perusahaan manufaktur yang go public melainkan juga dapat diaplikasikan untuk perusahaan-perusahaan di sektor swasta. Karena banyak perusahaan yang tidak go public sehingga tidak mempunyai nilai pasar. Maka Altman mengembangkan model alternatif dengan mengantikan variabel $\mathrm{X} 4$ yang semula merupakan perbandingan nilai pasar modal dengan nilai buku total hutang menjadi perbandingan nilai saham biasa dengan nilai buku total 37 hutang. Maka rumus untuk perusahaan yang tidak go public dirubah menjadi sebagai berikut:

Keterangan:

$$
\mathrm{Z}=0,717 \mathrm{X} 1+0,847 \mathrm{X} 2+3,107 \mathrm{X} 3+0,420 \mathrm{X} 4+0,988 \mathrm{X} 5
$$

$$
\begin{aligned}
& \mathrm{Z}=\text { Bankruptcy Index } \\
& \mathrm{X}_{1}=\text { Working Capital /Total Assets } \\
& \mathrm{X}_{2}=\text { Retained Earnings / Total Assets } \\
& \mathrm{X}_{3}=\text { Earning Before Interest And Taxes / Total Assets } \\
& \mathrm{X}_{4}=\text { Book Value Of Equity /Book Value Of Total Liabilities } \\
& \mathrm{X}_{5}=\text { Sales /Total Assets }
\end{aligned}
$$

Dapat diklasifikasikan tingkat kesehatan perusahaan menggunakan metode Altman Revisi pada tahun 1983 menjadi tiga kategori, yaitu: a). Jika nilai $Z<1,23$ artinya perusahaan yang bersangkutan mengalami distress atau kesulitan dalam keuangan dan potensial bangkrut. b). Jika nilai yang diperoleh $1,20<\mathrm{Z}<2,9$ artinya perusahaan termasuk kedalam kategori grey area, dimana pada kondisi ini tidak dapat ditentukan apakah perusahaan tersebut dalam keadaan sehat atau mengalami distress. c). Dan jika diperoleh nilai Z $>2,9$ artinya perusahaan tergolong sehat dan tidak bangkrut.

3). Metode Altman Modifikasi (1995); Seiring berjalannya waktu dan penyesuaian terhadap berbagai jenis perusahaan. Altman kemudian memodifikasi modelnya agar dapat diterapkan pada semua perusahaan seperti manufaktur, non manufaktur, dan perusahaan penerbit obligasi di negara berkembang. Setelah melakukan penelitian dengan objek berbagai perusahaan manufaktur dan menghasilkan dua rumus untuk mendeteksi kebangkrutan. Altman melakukan penelitian lagi dan menghasilkan rumusan Z-Score yang sangat fleksibel sehingga bisa digunakan untuk berbagai jenis bidang perusahaan. Kemudian Altman memodifikasi dengan mengeliminasi variabel X5 yaitu Sales To Total Asset. Karena rasio ini sangat bervariatif pada industri dengan ukuran aset yang berbeda-beda. Berikut persamaan Z-Score yang di modifikasi Altman et al 1995:

Keterangan:

$$
Z=6,56 \times 1+3,26 \times 2+6,72 \times 3+1,05 X 4
$$

$$
\begin{aligned}
& \mathrm{Z}=\text { Bankruptcy Index } \\
& \mathrm{X}_{1}=\text { Working Capital } / \text { Total Assets } \\
& \mathrm{X}_{2}=\text { Retained Earnings } / \text { Total Assets } \\
& \mathrm{X}_{3}=\text { Earning Before Interest And Taxes / Total Assets } \\
& \mathrm{X}_{4}=\text { Total Equity / Total Debt Ratio }
\end{aligned}
$$

Pengklasifikasikan tingkat kesehatan perusahaan menggunakan metode Altman Modifikasi pada tahun 1995, berdasarkan cut off yang sudah ditentukan menjadi tiga kategori, yaitu: a). Jika nilai $\mathrm{Z}<1,1$ artinya perusahaan yang bersangkutan mengalami distress atau kesulitan dalam keuangan dan potensial bangkrut. b). Jika nilai yang diperoleh $1,1<\mathrm{Z}<2,6$ artinya perusahaan termasuk kedalam kategori grey area, dimana 
pada kondisi ini tidak dapat ditentukan apakah perusahaan tersebut dalam keadaan sehat atau mengalami distress. c). Jika diperoleh nilai $\mathrm{Z}>2,6$ artinya perusahaan tergolong sehat dan tidak bangkrut.

\section{Metode Grover}

Grover mengklasifikasikan nilai kebangkrutan perusahaan jika Score $\leq-0,02$ maka perusahaan dalam keadaan bangkrut, jika Score $\geq 0,01$ maka perusahaan dalam keadaan sehat (tidak bangkrut), dan perusahaan dengan skor di antara batas atas dan batas bawah berada pada grey area. Grover (2001) menghasilkan fungsi sebagai berikut (Prihanthini dan Sari, 2013):

$$
\text { Score }=1,650 \mathrm{X} 1+3,404 \mathrm{X} 2+0,016 \mathrm{X} 3+0,057
$$

Keterangan :

$\mathrm{X}_{1}=$ Working Capital to Total Assets

$\mathrm{X}_{2}=$ Earnings Before Interest and Taxes to Total Assets

$\mathrm{X}_{3}=$ Net Income to Total Assets

\section{Kerangka Konseptual}

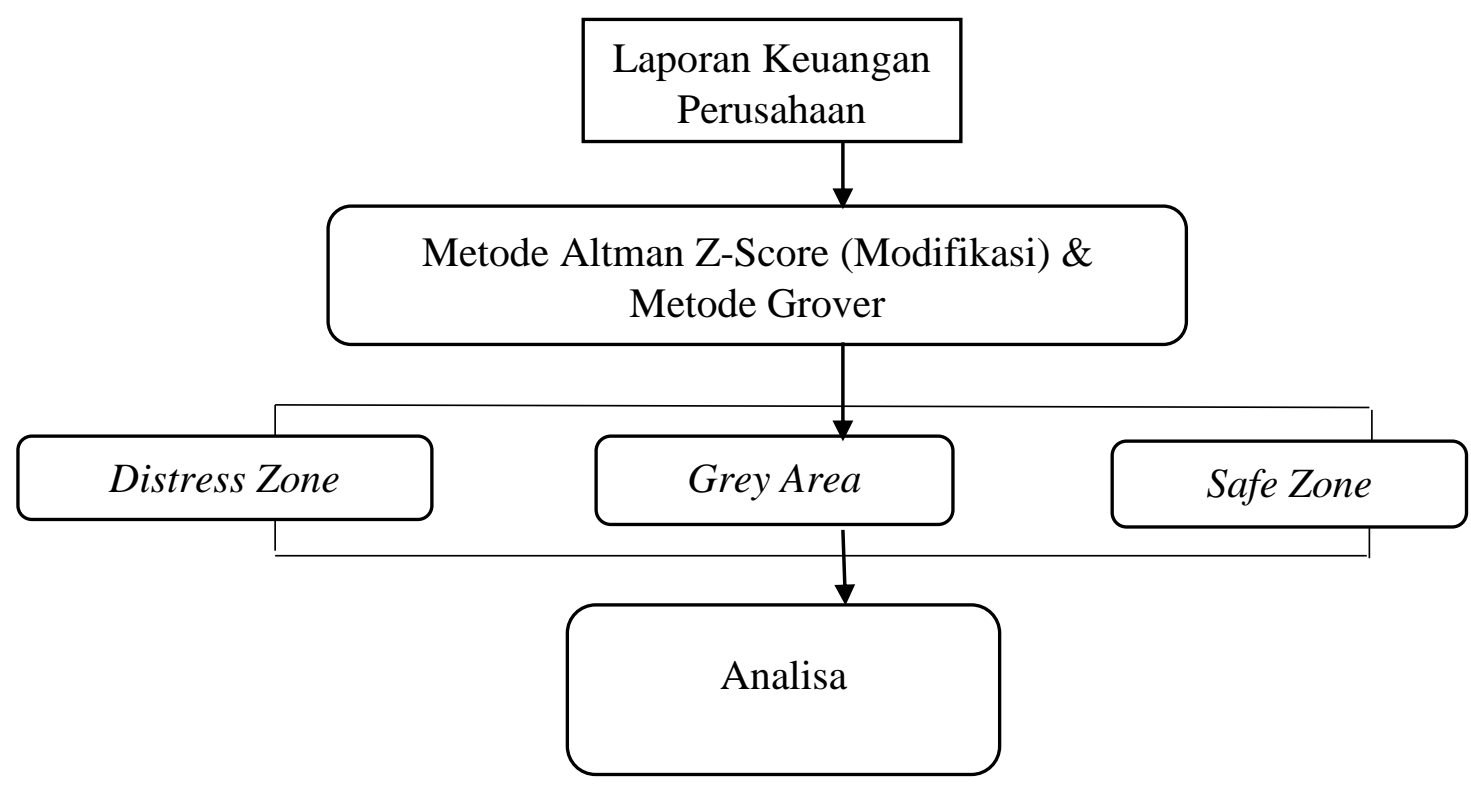

\section{METODE PENELITIAN}

Objek Penelitian

Objek yang diteliti adalah perusahaan sub sektor coal mining yang terdaftar dalam Indeks SMC-Liquid periode Agustus 2020-Januari 2021 dengan menggunakan laporan keuangan tahun 2017-2020. Perusahaan yang diteliti yakni PT Adaro Energy Tbk (ADRO), PT Indika Energy Tbk (INDY), PT Indo Tambangraya Megah Tbk (ITMG) dan PT Bukit Asam Tbk (PTBA).

Definisi Operasional Variabel 
Variabel yang diteliti dalam penelitian ini berkaitan dengan analisis metode Altman Z-Score yang sudah dimodifikasi terdapat empat rasio diantaranya adalah Working Capital to Total Assets, Retained Earnigs to Total Assets, Earning Before Interest and Taxes to Total Assets, dan Total Equity to Total Debt Ratio. Analisa kebangkrutan dengan metode Grover terdapat tiga rasio diantaranya adalah Working Capital to Total Assets, Earning Before Interest and Taxes to Total Assets dan Nett Income to Total Assets. Agar penelitian ini dapat dilakukan sesuai harapan, perlunya memahami definisi dari setiap rasio-rasio metode Altman Modifikasi.

Working capital to total assets atau rasio modal kerja terhadap total aset dapat menunjukkan kemampuan perusahaan dalam menghasilkan modal kerja dari seluruh asetnya. Menurut definisi Jumingan (2006), modal kerja diartikan sebagai jumlah aktiva lancar pada neraca perusahaan dan konsep modal kerja bersih adalah pengurangan antara aktiva lancar dengan kewajiban lancar. Dengan demikian diketahui bahwa terdapat modal kerja bersih dan modal kerja total. Dari perhitungan antara aktiva lancar dan kewajiban lancar maka akan menghasilkan modal kerja bersih serta diketahui rasio likuiditas perusahaan.

Retained earnings to total assets atau rasio laba ditahan terhadap total aset dapat digunakan untuk mengevaluasi tingkat keberhasilan suatu perusahaan dalam menghasilkan laba ditahan dari aset yang dimiliki perusahaan. Laba ditahan merupakan laba yang dihasilkan dari kegiatan usaha perusahan dan tidak dibagikan kepada investor dalam bentuk dividen.

Earning before interest and taxes to total assets atau rasio laba sebelum bunga dan pajak terhadap total aset menggambarkan kemampuan perusahaan menggunakan asetnya untuk menghasilkan laba sebelum membayar bunga dan pajak. Jika diketahui rasio EBIT terhadap total aset sangat lemah, hal tersebut dapat mengindikasikan bahwa perusahaan yang bersangkutan dapat mengalami kebangkrutan.

Total equity to total debt ratio atau rasio total modal terhadap total hutang ini berguna untuk mengukur tingkat leverage suatu perusahaan. Rasio ini digunakan untuk mengukur tingkat pengelolaan sumber dana perusahaan. Ini juga menunjukkan tingkat solvabilitas yang menggambarkan kemampuan perusahaan dalam menjamin semua kewajibannya.

Nett income to total assets atau rasio laba bersih terhadap total aset menggambarkan sejauh mana kemampuan asset-aset yang dimiliki perusahaan dapat menghasilkan laba bersih. Semakin tinggi hasil pengembalian atas aset berarti semakin tinggi pula jumlah laba bersih yang dihasilkan dari setiap rupiah dana yang tertanam dalam total aset. Sebaliknya, semakin rendah hasil pengembalian atas aset berarti semakin rendah pula jumlah laba bersih yang dihasilkan dari setiap dana yang tertanam dalam total aset.

\section{Teknik Analisis Data}

1. Mengumpulkan data berupa laporan keuangan perusahaan sub sektor coal mining tahun 2017-2020 yang terdaftar di Indeks SMC Liquid Bursa Efek Indonesia periode Agustus 2020-Januari 2021.

2. Penghitungan data-data laporan keuangan dengan menggunakan setiap metode yaitu metode analisis kebangkrutan Altman Z-Score dan Grover. Dari setiap perhitungan tersebut, ditentukan prediksi metode terhadap perusahaan (apakah akan mengalami distress atau tidak). 
3. Melakukan perhitungan tingkat akurasi pada setiap metode kebangkrutan untuk menilai metode kebangkrutan mana yang merupakan prediktor paling baik diantara kedua metode kebangkrutan tersebut.

\section{HASIL PENELITIAN}

Berdasarkan penerapan metode Z-Score yang telah dilakukan pada masing-masing perusahaan yang menjadi sampel telah diketahui masing-masing prediksi kebangkrutannya. Maka klasifikasi prediksi kebangkrutan dengan metode Z-Score seluruh perusahaan dapat diringkas dan disajikan dalam Tabel 1 sebagai berikut:

Tabel 1: Klasifikasi Hasil Perhitungan Metode Z-Score pada Seluruh Sampel Periode 2017-2020

\begin{tabular}{cccccr}
\hline \multirow{2}{*}{ Kode Saham } & \multicolumn{4}{c}{ Tahun } & \multirow{2}{*}{ Rata-Rata } \\
\cline { 2 - 5 } & $\mathbf{2 0 1 7}$ & $\mathbf{2 0 1 8}$ & $\mathbf{2 0 1 9}$ & $\mathbf{2 0 2 0}$ & \\
\hline ADRO & 4,6185 & 4,2130 & 3,6996 & 3,8097 & 4,0852 \\
INDY & 2,2737 & 3,3134 & 2,7331 & 2,1949 & 2,6288 \\
ITMG & 8,1012 & 7,2119 & 6,5295 & 6,0167 & 6,9648 \\
PTBA & 7,7371 & 8,0222 & 7,6988 & 6,5311 & 7,4973 \\
\hline
\end{tabular}

Berdasarkan hasil klasifikasi dalam Tabel 1, dapat dilihat bahwa empat perusahaan dengan jangka periode empat tahun tidak mengalami kebangkrutan dengan nilai rata-rata diatas 2,6. PT Adaro Energy Tbk, PT Indo Tambangraya Megah Tbk dan PT Bukit Asam Tbk selama periode penelitian berada dalam zona sehat dan tidak mengalami kebangkrutan. Hasil akumulasi tentunya juga menempatkan perusahaan tersebut memiliki rata-rata nilai $\mathrm{Z}$ juga berada dalam zona sehat dan tidak mengalami kebangkrutan. Hal ini menandakan bahwa PT Adaro Energy Tbk, PT Indo Tambangraya Megah Tbk dan PT Bukit Asam Tbk cenderung berada dalam prediksi sehat dan tidak mengalami kebangkrutan berdasarkan penerapan metode Altman Z-Score Modifikasi. PT Indika Energy Tbk pada tahun 2017 berada dalam kategori grey area namun di tahun 2018 mengalami peningkatan sehingga berhasil keluar dari kategori grey area menuju kategori sehat dan tidak mengalami kebangkrutan dengan nilai Z sebesar 3,3134. Pada tahun 2019, PT Indika Energy Tbk mengalami penurunan namun tidak sampai keluar dari zona sehat dan tidak mengalami kebangkrutan. Tahun 2020 penurunan terus berlanjut hingga menyebabkan PT Indika Energy Tbk keluar dari zona sehat dan berada dalam kategori grey area dengan nilai Z sebesar 2,1949 atau dibawah kriteria sehat $(2,6)$. Hasil rata-rata nilai Z PT Indika Energy Tbk selama empat periode berada dalam kriteria sehat dan tidak mengalami kebangkrutan dengan nilai Z-Score sebesar 2,6288.

Tabel 2: Klasifikasi Hasil Perhitungan Metode G-Score pada Seluruh Sampel Periode 2017-2020 


\begin{tabular}{|c|c|c|c|c|c|}
\hline \multirow{2}{*}{$\begin{array}{c}\text { Kode } \\
\text { Saham } \\
\end{array}$} & \multicolumn{4}{|c|}{ Tahun } & \multirow{2}{*}{$\begin{array}{l}\text { Rata- } \\
\text { Rata }\end{array}$} \\
\hline & 2017 & 2018 & 2019 & 2020 & \\
\hline ADRO & 0,8257 & 0,6712 & 0,5498 & 0,3611 & 0,6020 \\
\hline INDY & 0,4055 & 0,4443 & 0,8568 & 0,6532 & 0,5899 \\
\hline ITMG & 1,6024 & 1,5099 & 0,8891 & 0,6656 & 1,1668 \\
\hline PTBA & 1,4778 & 1,4096 & 1,1553 & 0,7233 & 1,1915 \\
\hline
\end{tabular}

Berdasarkan hasil klasifikasi dalam Tabel 2, dapat dilihat bahwa empat perusahaan dengan jangka periode empat tahun tidak mengalami kebangkrutan dengan nilai rata-rata diatas 0,01. PT Adaro Energy Tbk, PT Indo Tambangraya Megah Tbk dan PT Bukit Asam Tbk mengalami penurunan nilai $G$ di tahun 2018 dan penurunan berlanjut sampai tahun 2020. PT Indika Energy Tbk memiliki kondisi yang berbeda dibandingkan perusahaan lainnya dimana terjadi peningkatan nilai G-Score di tahun 2018 hingga 2019, sedangkan di tahun 2020 mengalami penurunan nilai G-Score.

Tabel 3: Hasil Prediksi Kebangkrutan Coal Mining di Indonesia

\begin{tabular}{|c|c|c|c|c|c|}
\hline \multirow{2}{*}{ Metode } & \multicolumn{4}{|c|}{ Tahun } & \multirow{2}{*}{$\begin{array}{l}\text { Rata- } \\
\text { Rata }\end{array}$} \\
\hline & 2017 & 2018 & 2019 & 2020 & \\
\hline Altman & 5,6826 & 5,6902 & 5,1653 & 4,6381 & 5,2940 \\
\hline Grover & 1,0779 & 1,0088 & 0,8628 & 0,6008 & 0,8876 \\
\hline
\end{tabular}

Berdasarkan table diatas dapat disimpulkan bahwa dari tahun 2017 sampai dengan tahun 2020 semua perusahaan dengan metode Altman diprediksi dalam kondisi sehat dan tidak bangkrut karena nilai rata-rata diatas 2,6. Metode Grover juga diprediksi semua perusahaan dalam kondisi sehat dan tidak bangkrut karena nilai rata-rata diatas 0,01.

\section{Pembahasan}

Hasil perhitungan nilai Z-Score dan Grover terhadap seluruh perusahaan sampel menunjukkan ada perbedaan hasil selama empat periode. Dimana Z-Score yang dihasilkan tiga perusahaan ada yang lebih tinggi dari 2,6 atau selalu berada diatas 2,6 dan satu perusahaan memiliki nilai Z-Score yang lebih tinggi dari 2,6 hanya pada tahun kedua dan ketiga selama periode penelitian. Namun secara rata-rata nilai Z-Score keempat perusahaan berada diatas 2,6 selama empat periode. Sementera itu, baik nilai Grover per tahun maupun nilai rata-rata yang dihasilkan keempat perusahaan dalam kondisi sehat dan tidak mengalami kebangkrutan.

Hasil analisis dari dua metode yang digunakan serta perhitungan statistic. Metode Grover yang lebih akurat dibandingkan dengan metode Altman Z-Score dengan menghitung standar deviasinya. Nilai standar deviasi yang rendah menunjukkan bahwa titik data cenderung sangat dekat dengan mean (rata-rata) sehingga tingkat akuratnya tinggi, sedangkan nilai standar deviasi yang tinggi menunjukkan bahwa data semakin bervariasi dan jauh dari nilai rata-ratanya sehingga memiliki tingkat akurasi yang rendah. Perhitungan standar deviasi rata-rata metode Grover nilai paling kecil dan mendekati mean (rata-rata) yakni sebesar 0,37, sedangkan untuk Altman sebesar 2,32. Maka dapat disimpulkan bahwa metode Grover yang memiliki tingkat keakuratan yang lebih tinggi dibandingkan metode lainnya. Hal ini ditunjukkan oleh perhitungan dari analisis Grover yang lebih memfokuskan pada nilai laba yang diperoleh. Semakin rendah nilai laba suatu perusahaan menunjukkan 
bahwa perusahaan tersebut memiliki tingkat profitabilitas yang rendah sehingga membuat perusahaan tersebut bangkrut.

Satu dari empat perusahaan yang diprediksi mendekati grey area dalam metode Altman yakni PT Indika Energy Tbk. Hal tersebut dikarenakan perusahaan tersebut mengalami penurunan nilai terhadap kemampuan perusahaan untuk menghasilkan modal kerja bersih dari total aset, kemampuan perusahaan dalam menghasilkan laba ditahan dan kemampuan perusahaan dalam menghasilkan laba dari total aset serta adanya kenaikan dari total hutang selama periode 2017-2020. Sementara itu metode Grover menyatakan tidak ada perusahaan yang diprediksi mengalami kebangkrutan. Hal tersebut dikarenakan kemampuan perusahaan dalam menghasilkan modal kerja bersih dari total aset, laba sebelum bunga dan pajak terhadap total aset dan pendapatan bersih terhadap total aset. Sehingga dapat dipastikan bagi perusahaan yang memiliki permasalahan dalam kemampuan untuk menghasilkan modal kerja, maka perusahaan tersebut akan mengalami kesulitan dalam menutupi kewajiban jangka pendeknya karena ketidaksediaannya aset lancar yang cukup untuk menutupi kewajiban tersebut.

\section{KESIMPULAN}

Hasil rata-rata nilai metode Altman Z-Score selama periode 2017-2020 empat emiten perusahaan sub sektor coal mining yaitu PT Adaro Energy Tbk, PT Indo Tambangraya Megah Tbk, PT Indika Energy Tbk dan PT Bukit Asam Tbk mengalami kondisi sehat dan tidak bangkrut namun nilai PT Indika Energy Tbk mendekati kategori grey area dengan nilai $\mathrm{Z}$ sebesar 2,62. Pada metode Grover mengindikasikan keempat perusahaan dalam kondisi tidak mengalami kebangkrutan dengan nilai rata-rata diatas 0,01 .

\section{DAFTAR PUSTAKA}

Altman, Edward; Edith Hotchkiss. 2005. Corporate Financial Distress and Bankruptcy, 3rd edition. John Wiley and Sons. ISBN 0-471-55253-4.

Brahmana, Rayenda. K. 2007. Identifying Financial Distress Condition in Indonesia Manufacture Industry. Birmingham Business School, University of Birmingham United Kingdom. Halaman 1-19

Darsono, \& Ashari. 2005. Pedoman Praktis Memahami Laporan Keuangan. Yogyakarta: Andi.

Effendi, Ria. 2018. Analisis Prediksi Kebangkrutaan dengan Metode Altman, Springate, Zmijewski, Foster dan Grover Pada Emiten Jasa Transportasi. E-Jurnal Parsimonia Universitas Ma Chung Vol 4 No 3, 307-318. Malang.

Fahmi, I. 2011. Analisis Kinerja Keuangan. Lampulo: Alfabeta

Fatmawati, M. 2012. Penggunaan The Zmijewski Model, The Altman Model, dan The Springate Model sebagai Prediktor Delisting. Jurnal Keuangan dan Perbankan. Vol. 16 No. 1 , hlm. 56-65.

Grover, J., \& Lavin, A. 2001. Financial Ratios, Discriminant Analysis and The Prediction of Corporate Bankruptcy: a Service Industry Extension of Altman's Z-Score Model of Bankruptcy Prediction. Working Paper. Southern Finance Assosiation Annual Meeting.

Harahap, Sofyan Syarif. 2004. Analisis Kritis Atas Laporan Keuangan. Jakarta. PT Raja Grafindo Persada

Jumingan. 2006. Analisis Laporan Keuangan. Jakarta: PT Bumi Aksara. 
Prihanthini, N.M.E.D; Sari, M.M.R. 2013. Prediksi Kebangkrutan Dengan Model Grover, Altman Z-Score, Springate, dan Zmijewski Pada Perusahaan Food and Beverage Di Bursa Efek Indonesia. E-Jurnal Akuntansi Universitas Udayana 5.2, 417-435. Bali.

Pustylnick, 1. 2012. "Restructuring The Financial Characteristics of Projects in Financial Distress". Global Journal of Business Research. Vol. 6, No.2. Hlm. 125-134.

Sugiyono. 2014. Metode Penelitian Kuantitatif, Kualitatif, dan Kombinasi (Mixed Methods). Bandung: Alfabeta. 